TAPROBANICA, ISSN 1800-427X. October, 2010. Vol. 02, No. 02: pp. 95-96, 1 pl.

(C) Taprobanica Nature Conservation Society, 146, Kendalanda, Homagama, Sri Lanka.

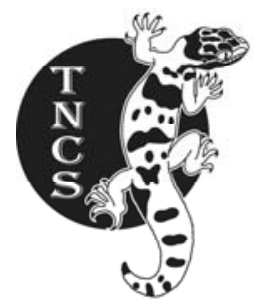

\title{
TWO NEW MELIOLACEAE MEMBERS FROM KERALA, INDIA
}

Sectional Editor: Kevin Hyde

Submitted: 14 February 2011, Accepted: 22 April 2011

V.B. Hosagoudar* and A. Sabeena

Tropical Botanic Garden \& Research Institute, Palode - 695 562, Thiruvananthapuram, Kerala, India

* E-mail: vbhosagoudar@rediffmail.com

\begin{abstract}
This paper gives an account of two new species, namely, Asteridiella sebastianiae and Meliola gluticola, infecting leaves of Sebastiania chamaelea and Gluta travancorica. Both these fungal species are new and are described, illustrated and compared with most similar taxa.
\end{abstract}

Key words: New species, fungi, Asteridiella, Meliola, Sebastiania chamaelea, Gluta travancorica

\section{Introduction}

During a survey of the foliicolous fungi of Garden plants in Kerala State, Sebastiania chamaelea and Gluta travancorica were found infected with black mildew fungi. Critical examination of these fungi revealed that both are hitherto undescribed species of the genera Asteridiella and Meliola. Part of the collections has been deposited in Herbarium Cryptogamae Indiae Orientalis (HCIO), New Delhi as isotypes.

\section{Taxonomy}

1. Asteridiella sebastianiae Hosagoudar, Sabeena et Jacob-Thomas, sp. nov. (Fig. 1)

Coloniae amphigenae, tenues, ad $2 \mathrm{~mm}$ diam., confluentes. Hyphae subrectae, flexuosae vel anfractuae, opposite vel unilateralis acuteque vel laxe ramosae, cellulae 20-50 x 6-9 $\mu$ m. Appressoria alternata vel unilateralis, antrorsa, subantrorsa vel retrorsa, recta to curvula, 18-29 $\mu \mathrm{m}$ longa; cellulae basilares cylindraceae vel cuneatae, 4-9 $\mu \mathrm{m}$ longae; cellulae apicales ovatae, globosae, integrae, angularis, $13-20 \times 9-13 \mu \mathrm{m}$. Phialides appressoriis intermixtae, alternatae vel oppositae, ampulliformes, 15-24 x 6-9 $\mu \mathrm{m}$. Perithecia globosa, dispersa, ad $172 \mu \mathrm{m}$ in diam.; cellulae peritheciales conoideae, ad $26 \mu \mathrm{m}$ longae; ascosporae oblongae, ellipsoideae vel cylindraceae, 4-septatae, constrictus ad septatae, 31-37 x 9-13 $\mu \mathrm{m}$.

Colonies amphigenous, thin, up to $2 \mathrm{~mm}$ in diameter, confluent. Hyphae substraight, flexuous to crooked, branching opposite to unilateral at acute to wide angles, cells 20-50 x 6-9 $\mu \mathrm{m}$. Appressoria alternate to unilateral, antrorse, subantrorse to 
retrorse, straight to curved, 18-29 $\mu \mathrm{m}$ long; stalk cells cylindrical to cuneate, 4-9 $\mu \mathrm{m}$ long; head cells ovate, globose, entire, angular, 13-20 x 9-13 $\mu \mathrm{m}$. Phialides mixed with appressoria, alternate to opposite, ampulliform, 15-24 x 6-9 $\mu \mathrm{m}$. Perithecia globose, scattered, up to $172 \mu \mathrm{m}$ in diameter; perithecial cells conoid, up to $26 \mu \mathrm{m}$ long; ascospores oblong, ellipsoidal to cylindrical, 4septate, constricted at the septa, 31-37 x 9-13 $\mu \mathrm{m}$.

\section{Material examined: type}

On leaves of Sebastiania chamaelea (L.) Mull. (Euphorbiaceae); Cat. no. HCIO 48046; Loc. Tropical Botanic Garden \& Research Institute (TBGRI) Campus, Palode, Thiruvananthapuram, Kerala, India; Coll. A. Sabeena et al.; Date. 14-V-2007. Isotype, Cat. no. TBGT 2829

Asteridiella sebastianiae can be compared with Asteridiella phyllanthi (Deight.) Hansford, A. erythrococcae Hansford, A. hansfordii (Stev.) Hansford var. densa (Hansford \& Deight.) Hansford, A. macarangicola Hosagoudar and A. wayanadensis Hosagoudar et al. (Biju et al., 2005; Hansford, 1961; Hosagoudar, 1996 \& 2008; Hosagoudar \& Agarwal, 2008) having the beeli formula 3101. 3220. However, it differs from $A$. phyllanthii, A. hansfordii var. densa, A. macarangicola and $A$. combeensis in having distinctly narrow ascospores (9-13 $\mu \mathrm{m}$ against 16$18 \mu \mathrm{m})$. It differs from A. erythrococcae in having entire head cells of the appressoria in contrast to angulose to sublobate. Asteridiella sebastianiae also differs from $A$. wayanadensis in having longer, antrorse to retrorse appressoria. This is the first report of meliolaceous fungi on this host genus.

2. Meliola gluticola V. B. Hosagoudar and A. Sabeena sp. nov. (Fig. 2)

Coloniae amphigenae, plerumque hypophyllae, tenues, ad $4 \mathrm{~mm}$ diam., confluentes. Hyphae rectae vel subrectae, opposite acuteque vel laxe ramosae, cellulae 13-20 x 6-9 $\mu \mathrm{m}$. Appressoria alternata, dense posita, antrorsa vel subantrorsa, 15-20 $\mu \mathrm{m}$ longa; cellulae basilares cylindraceae vel cuneatae, 2-6 $\mu \mathrm{m}$ longae; cellulae apicales ovatae, integrae, 13-15 x 6-9 $\mu \mathrm{m}$. Phialides appressoriis intermixtae, alternatae vel oppositae, ampulliformes, 15-22 x 6-9 $\mu \mathrm{m}$. Setae myceliales simplices, rectae, ad apicem acutae vel obtusae, ad $330 \mu \mathrm{m}$ longae. Perithecia dispersa, ad $110 \mu \mathrm{m}$ diam.; ascosporae cylindraceae, 4-septatae, constrictus ad septatae, 39$44 \times 15-17 \mu \mathrm{m}$.
Colonies amphigenous, mostly hypophyllous, thin, upto $4 \mathrm{~mm}$ in diameter, confluent. Hyphae, straight to substraight, branching opposite at acute to wide angles, cells 13-20 x 6-9 $\mu \mathrm{m}$. Appressoria alternate, closely arranged on the hyphae antrorse to subantrorse, $15-20 \mu \mathrm{m}$ long; stalk cells cylindrical to cuneate, 2-6 $\mu \mathrm{m}$ long; head cells ovate, entire, 13-15 x 6-9 $\mu \mathrm{m}$. Phialides mixed with appressoria, alternate to opposite, ampulliform, 15-22 x 6-9 $\mu \mathrm{m}$. Mycelial setae simple, straight, acute to obtuse at the tip, up to $330 \mu \mathrm{m}$ long. Perithecia scattered, up to $110 \mu \mathrm{m}$ in diameter; ascospores cylindrical, 4septate, constricted at the septa, 39-44 x 15-17 $\mu \mathrm{m}$.

\section{Material examined: type}

On leaves of Gluta travancorica L. (Anacardiaceae); Cat. no. HCIO 48337; Loc. TBGRI Campus, Palode, Thiruvananthapuram, Kerala, India; Coll. A. Sabeena et al.; Date. 10-X-2007. Isotype, Cat. no. TBGT 3058

Gluta travancorica L. is an endemic plant and Meliola glutae is known to infect this plant (Hosagoudar, 1996 \& 1998; Hosagoudar \& Agarwal, 2008; Hosagoudar et al., 1997). However, differs from it in having regularly antrorse to subantrorse appressoria with ovate to oblong and entire head cells. The colonies of both these species were mixed together but can be easily distinguished based on the above characters.

\section{Acknowledgement}

We thank the Director (TBGRI) for providing facilities.

\section{Literature Cited}

Biju, C. K., V. B. Hosagoudar and T. K. Abraham, 2005. Meliolaceae of Kerala, India - XV. Nova Hedwigia, 80: 465-502.

Hansford, C. G., 1961. The Meliolineae. A Monograph. Sydowia Beih. 2: 806.

Hosagoudar, V. B., 1996. Meliolales of India. Botanical Survey of India, Calcutta: 363.

Hosagoudar, V. B., 2008. Meliolales of India. Vol. II. Botanical Survey of India, Calcutta: 390.

Hosagoudar, V. B. and D. K. Agarwal, 2008. Taxonomic studies of Meliolales. Identification Manual. International Book Distributors, Dehra Dun: 263.

Hosagoudar, V. B., T. K. Abraham and P. Pushpangadan, 1997. The Meliolineae - A Supplement. Tropical Botanic Garden and Research Institute, Palode, Thiruvananthapuram, Kerala, India: 201. 


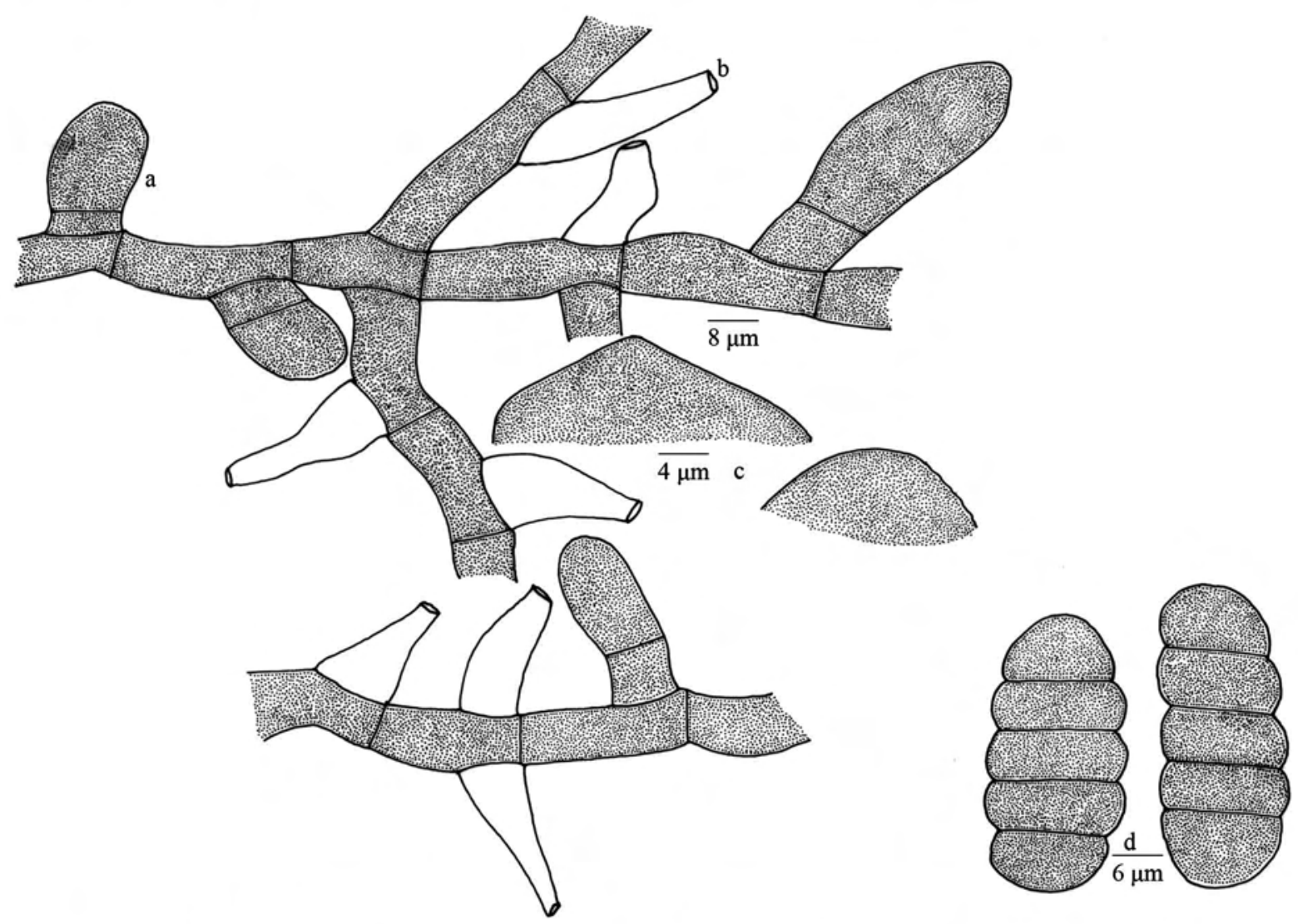

Fig. 01: Asteridiella sebastianiae V. B. Hosagoudar, A. Sabeena \& J. Thomas, sp. nov.

a. Appressoriate mycelium, b. Phialide, c. Perithecial wall cells, d. Ascospores

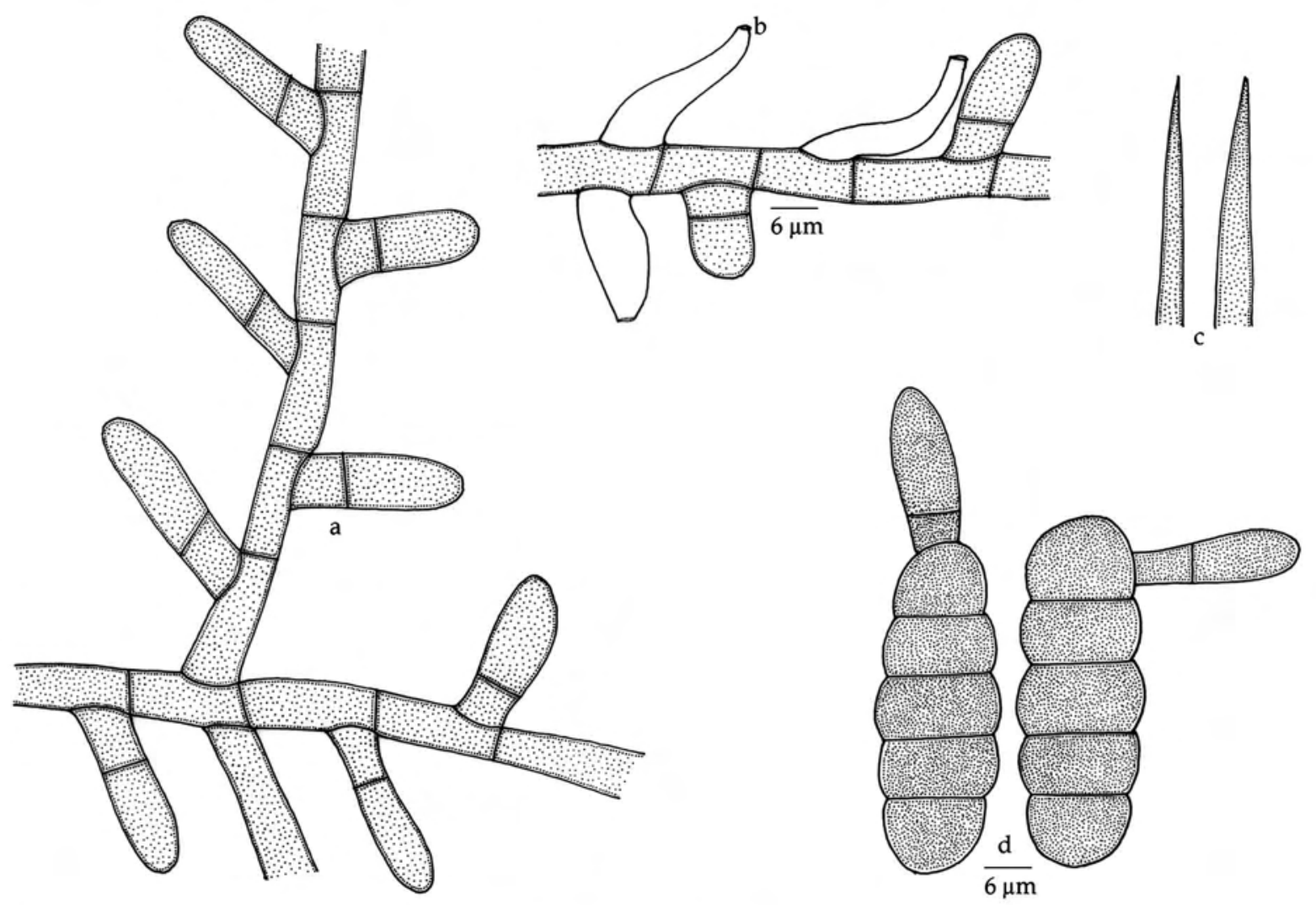

Fig. 02: 2. Meliola gluticola V. B. Hosagoudar \& A. Sabeena sp. nov.

a. Appressoriate mycelium, b. Phialide, c. Apical portion of mycelial setae, d. Ascospores 